Volume 2 Nomor 1 Edisi Juni 2013

ISSN 2354-7200
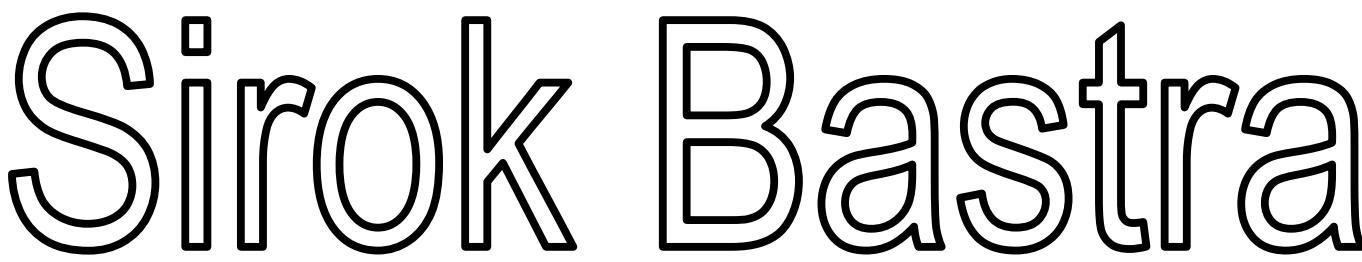

JURNAL ILMIAH KEBAHASAAN DAN KESASTRAAN

\begin{tabular}{|c|c|l|c|c|c|}
\hline $\begin{array}{c}\text { Sirok Bastra } \\
\text { Jurnal Kebahasaan dan } \\
\text { Kesastraan }\end{array}$ & Volume 2 & Nomor 1 & $\begin{array}{c}\text { Hlm. } \\
1-120\end{array}$ & $\begin{array}{c}\text { Pangkalpinang, } \\
\text { Juni 2013 }\end{array}$ & $\begin{array}{c}\text { ISSN } \\
2354-7200\end{array}$ \\
\hline
\end{tabular}

KANTOR BAHASA PROUINSI BANGKA BELITUNG 


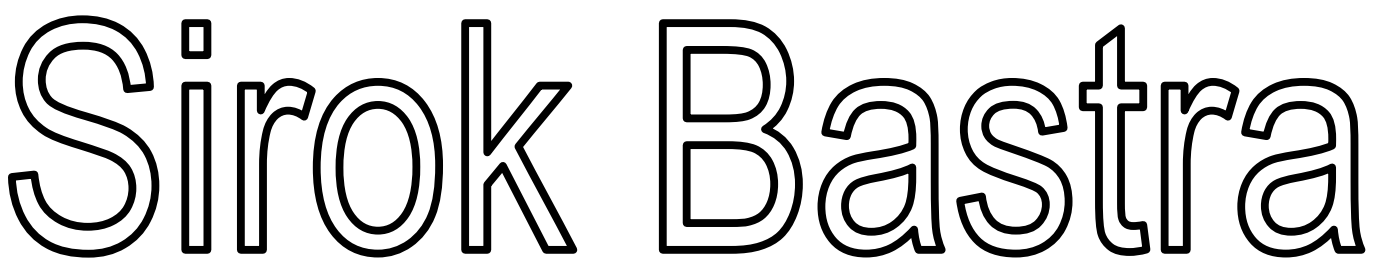

\section{JURNAL ILMIAH KEBAHASAAN DAN KESASTRAAN}

Jurnal ini merupakan wadah informasi mengenai kebahasan, kesastraan, dan pengajarannya yang memuat hasil penelitian, studi kepustakaan, dan tulisan ilmiah bidang kebahasan dan kesastraan serta pengajarannya. Sirok Bastra terbit dua kali setahun, yakni Juni dan Desember, serta terbit sejak Juni 2013.

\section{Penanggung Jawab}

Kepala Kantor Bahasa Provinsi Bangka Belitung Drs. Umar Solikhan, M.Hum.

\section{Mitra Bestari}

Prof. Dr. Agus Nuryatin, M.Hum. (Bidang Sastra dan Pengajarannya)

Prof. Amrin Saragih, Ph.D., M.A. (Bidang Bahasa dan Pengajarannya)

Dr. Felicia Nuradi Utorodewo, M.Hum. (Bidang Bahasa dan Pengajarannya)

Dr. Pujiharto, M.Hum. (Bidang Sastra dan Pengajarannya)

\section{Pemimpin Redaksi}

Rahmat Muhidin, S.S.

\section{Penyunting}

Prima Hariyanto, S.Hum.

\section{Perancang Sampul}

Feri Pristiawan, S.S.

\section{Kesekretariatan}

Khaliffitriansyah, S.Pd.

Dea Letriana Cesaria, S.Hum.

Lia Aprilina, S.Pd.

Andrian Priyatno, A.Md.

Elzam

\section{Alamat Redaksi dan Penerbit}

Kantor Bahasa Provinsi Bangka Belitung

Ruko Permata 7, Jalan Solihin G.P. Km 4, Kota Pangkalpinang, Prov. Kepulauan Bangka Belitung

Telp./Faks.: 0717-438455, Pos-el: sirokbastra@gmail.com

Pemuatan suatu tulisan dalam jurnal ini tidak berarti redaksi menyetujui isi tulisan tersebut. Isi tulisan menjadi tanggung jawab penulis. Tulisan telah ditinjau dan diulas oleh mitra bestari. Setiap karangan dalam jurnal ini dapat diperbanyak setelah mendapat izin tertulis dari penulis, redaksi, dan penerbit. 


\section{PENGANTAR}

Puji syukur ke hadirat Pemilik dan Pencipta semesta ini yang memiliki kuasa atas diri-Nya sendiri. Dialah Tuhan Yang Maha Esa yang telah memberikan rahmat dan hidayah-Nya sehingga Volume 2 Nomor 1 Jurnal Sirok Bastra Tahun 2014 dapat terbit tepat pada waktunya.

Pada edisi ini, dimuat sepuluh tulisan, yakni enam tulisan kesastraan dan empat tulisan kebahasaan. Dalam kajiannya, Anita Rima Dewi melihat kedudukan perempuan Jawa dalam keluarga — tergambar dalam novel Hati Sinden karya Dwi Rahyuningsih — dilihat dari perspektif gender. Berdasarkan penelitian, ditemukan bahwa diskriminasi gender seperti marginalisasi, stereotipe, dan subordinasi melahirkan berbagai kekerasan, yakni ekonomi, fisik, psikis, dan seksual.

Dalam kajiannya, Sarman membahas mitos buluh perindu dalam cerita rakyat Bangka. Mitos Bukit Tambun Tulang memuat struktur geografis yang menunjukkan adanya pola perjalanan hidup tokoh dalam mempertahankan hidup; struktur tekno-ekonomi yang menunjukkan adanya sistem mata pencaharian orang Bangka, antara lain berburu dan berkebun; struktur sosiologis yang menunjukan adanya hubungan sosial antara sesama manusia; dan struktur kosmologis yang menunjukkan adanya keterkaitan antara dunia nyata dan dunia gaib.

Dalam penelitiannya, Iis Afriatiningsih membahas sosok perempuan dalam karya sastra Indonesia yang diwakili oleh Nyai Ontosoroh, Pariyem, Clara yang menghadapi banyak tantangan dalam hidupnya. Hasil analisis menunjukkan bahwa sosok perempuan memiliki sikap, seperti memperjuangkan hidupnya (tergambar dalam tokoh Nyai Ontosoroh), pasrah dengan nasibnya (tergambar dalam tokoh Pariyem), dan nasibnya ada di tangan rakyat kecil (tergambar dalam tokoh Clara). Perjuangan perempuan tersebut berkaitan dengan kritik formalisme, strukturalisme, posstrukturalisme, dan posmoderenisme.

Dalam kajiannya, Asep Supriadi mengaplikasikan teori takmilah yang digagas oleh seorang pakar sastra Melayu bernama Shafie Abu Bakar pada puisi "Idul Fitri" karya Sutardji Calzoum Bachri. Hasil kajian menunjukkan bahwa puisi tersebut menggambarkan nilai-nilai keislaman dengan dimensi sufistik. Puisi itu menggambarkan perenungan eksistensi diri pada Tuhan.

Dalam kajiannya, Ch. Haris Maulana membahas tokoh dan penokohan serta nilai moral dan kekhasan yang ada dalam serial Harry Potter, khususnya seri pertama, Harry Potter dan Batu Bertuah. Nilai moral dan kekhasan yang tersirat dalam serial ini adalah sihir dapat dipelajari dan bukan faktor keturunan, kesetiakawanan, kedisipilinan, kepedulian, dan keingintahuan.

Dalam penelitiannya, Dwi Oktarina menggali aspek hibriditas dan ambivalensi yang terjadi pada tokoh Mata Hari dalam novel Namaku Mata Hari karya Remy Silado. Mata Hari, seorang agen spionase keturunan Belanda-Jawa bekerja pada banyak negara pada saat perang dunia berkecamuk. Selain itu, permainan politik tubuh Mata Hari juga menjadi sebuah hal yang menarik untuk diteliti lebih jauh. Berdasarkan penelitian, didapatkan hasil bahwa ruang-ruang pertemuan antara dua kebudayaan sama sekali tidak bisa dielakkan. Mata Hari sebagai Indo berdarah campuran Belanda-Indonesia tidak dapat melepaskan dirinya dari dua kebudayaan yang melingkupinya, Belanda maupun Indonesia.

Dalam kajiannya, Maria Christa Istiana Kamagi membahas struktur kalimat dan keterbacaan pada buku teks pelajaran bahasa Indonesia. Berdasarkan penelitian, ditemukan kalimat tunggal perluasan subjek, predikat, objek, dan pelengkap, kalimat tunggal perluasan keterangan, kalimat majemuk setara, kalimat majemuk bertingkat, kalimat majemuk bersusun, dan kalimat taklengkap. Selain menjelaskan struktur kalimat yang ada, penelitian ini juga mencoba menganalisis keterbacaan dilihat dari jumlah kata yang digunakan dalam kalimat tersebut. Hasil yang didapat adalah terdapat beberapa kalimat yang masih masuk kategori kalimat sulit dan sangat sulit dipahami.

Dalam kajiannya, Achril Zalmansyah membahas hasil Uji Kemahiran Berbahasa Indonesia (UKBI) guru dan siswa SMP di Kabupaten Lampung Utara. Data yang diperoleh menunjukkan bahwa sebagian besar peserta memperoleh nilai antara 300-400 yang berarti cukup baik. Dengan demikian, dapat dikatakan bahwa UKBI 
merupakan alat uji yang dapat digunakan untuk mengukur penguasaan bahasa Indonesia seorang guru serta penggunaan bahasa Indonesia yang baik dan benar oleh siswa.

Dalam kajiannya, Prima Hariyanto membahas kata berinfiks -er- dalam bahasa Indonesia. Korpus data penelitian ini adalah Kamus Besar Bahasa Indonesia Edisi Ketiga. Berdasarkan penelitian yang dilakukan, ditemukan 62 kata berinfiks -er- yang terdiri dari 14 jenis kelompok makna. Selain memaparkan kata berinfiks yang ada, penelitian ini juga mencoba memaparkan metode pendefinisian lema kata berinfiks yang -er-bermakna 'sama dengan bentuk dasarnya' dalam Kamus Besar Bahasa Indonesia.

Dalam penelitiannya, Hotnida Novita Sary mengkaji perbedaan bentuk verba yang terdapat dalam bahasa Melayu Tinggi dan bahasa Melayu Rendah yang terdapat dalam Injil Matius terjemahan Klinkert. Peneliti mengunduh data dari laman sabda.org. Kedua versi Injil Matius ini kemudian dibandingkan dan dicatat satu ayat dengan ayat yang sama. Hasil pencatatan inilah yang dianalisis. Hasil yang didapatkan dari penelitian ini adalah ragam bahasa Melayu Tinggi cenderung menggunakan bentuk berimbuhan, sedangkan bahasa Melayu Rendah cenderung menggunakan bentuk dasar.

Kami mengucapkan terima kasih kepada para penulis yang telah bersedia menerbitkan karya mereka pada edisi ini. Para penulis merupakan peneliti, pakar, dosen, siswa, dan mahasiswa dari berbagai sekolah, perguruan tinggi, dan instansi. Terima kasih juga kami sampaikan kepada para mitra bestari kami yang telah memberi ulasan terhadap tulisan-tulisan yang masuk ke redaksi.

Demi memenuhi keberagaman isi dan penulis, Sirok Bastra membuka kesempatan bagi para peneliti dan penulis menyampaikan hasil penelitian dan pemikiran mutakhir dalam bidang kebahasaan, kesastraan, dan pengajarannya.

Pangkalpinang, Juni 2014

Tim Redaksi 


\section{UCAPAN TERIMA KASIH UNTUK MITRA BESTARI}

Redaksi Sirok Bastra mengucapkan terima kasih kepada para mitra bestari yang telah meninjau, menimbang, dan mengulas makalah-makalah yang diterbitkan dalam Sirok Bastra Volume 2 Nomor 1, edisi Juni 2014, yakni

Prof. Dr. Agus Nuryatin, M.Hum.

Bidang Sastra dan Pengajarannya

Universitas Negeri Semarang

Semarang, Jawa Tengah

Prof. Amrin Saragih, Ph.D., M.A.

Bidang Bahasa dan Pengajarannya

Universitas Negeri Medan

Medan, Sumatra Utara

Dr. Felicia Nuradi Utorodewo, M.Hum.

Bidang Bahasa dan Pengajarannya

Universitas Indonesia

Depok, Jawa Barat

\section{Dr. Pujiharto, M.Hum.}

Bidang Sastra dan Pengajarannya

Universitas Gadjah Mada

Yogyakarta, Daerah Istimewa Yogyakarta 


\section{DAFTAR ISI}

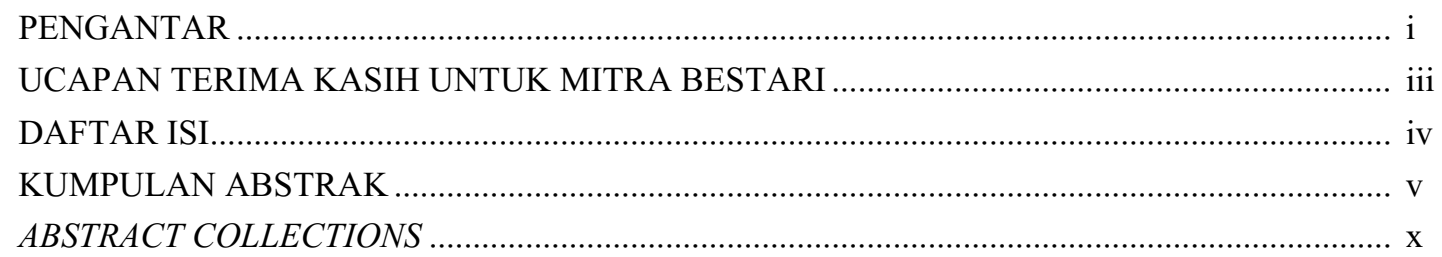

KEDUDUKAN PEREMPUAN JAWA DALAM NOVEL HATI SINDEN KARYA DWI RAHYUNINGSIH DILIHAT DARI PERSPEKTIF GENDER

(The Position of Javanese Women Based on Gender Perspective in Hati Sinden, a Novel by Dwi Rahyuningsih)

Anita Rima Dewi $1-15$

MITOS DALAM CERITA “BUKIT TAMBUN TULANG”

(Myth in "Bukit Tambun Tulang" Story)

Sarman. $17-24$

SOSOK PEREMPUAN DARI ZAMAN KE ZAMAN DALAM KARYA SASTRA INDONESIA: STUDI KASUS TOKOH NYAI ONTOSOROH, PARIYEM, DAN CLARA (Figure of Women from Time to Time in Indonesian Literary Works: A Case Study of Nyai Ontosoroh, Pariyem, and Clara)

Iis Afriatiningsih $25-33$

MEMAHAMI PUISI "IDUL FITRI" DENGAN TEORI TAKMILAH

(Understanding the Poetry "Idul Fitri” by Using Theory of Takmilah)

Asep Supriadi $35-44$

NILAI DAN KEKHASAN SERIAL HARRY POTTER (KAJIAN HARRY POTTER 1: HARRY POTTER DAN BATU BERTUAH)

(Value and Uniqueness of Harry Potter Series [A Study of Harry Potter 1: Harry Potter and The Sorcerers Stone])

Ch. Haris Maulana $45-52$

HIBRIDITAS DAN POLITIK TUBUH DALAM NOVEL NAMAKU MATA HARI KARYA REMY SILADO: SEBUAH TINJAUAN POSKOLONIAL

(Hybridity and Body Politic in Namaku Mata Hari, A Novel Written by Remy Silado: A Postcolonial Study)

Dwi Oktarina $53-61$

STRUKTUR DAN KETERBACAAN KALIMAT PADA BUKU TEKS PELAJARAN BAHASA INDONESIA

(Sentence Structure and Readability in Indonesian Textbook)

Maria Christa Istiana Kamagi. $63-78$ 
UJI KEMAHIRAN BERBAHASA INDONESIA (UKBI) BAGI GURU DAN SISWA SEKOLAH MENENGAH PERTAMA SE-LAMPUNG UTARA

(Indonesian Proficiency Test [UKBI] for Teacher and Junior High School Students All Lampung Utara)

Achril Zalmansyah

KATA BERINFIKS -ER- DALAM BAHASA INDONESIA

(-er- Infixes Words in Indonesian)

Prima Hariyanto

$89-103$

PERBEDAAN BENTUK VERBA PADA BAHASA MELAYU TINGGI DAN BAHASA

MELAYU RENDAH: STUDI KASUS INJIL MATIUS TERJEMAHAN KLINKERT

(Verb Form of Differences in Language Malay Malay Language High and Low: Case Study of The Gospel of Matthew Klinkert Translations)

Hotnida Novita Sary .... $105-120$ 
Hotnida Novita Sary: Perbedaan Bentuk Verba pada Bahasa Melayu Tinggi dan ...

\title{
PERBEDAAN BENTUK VERBA PADA BAHASA MELAYU TINGGI DAN BAHASA MELAYU RENDAH: STUDI KASUS INJIL MATIUS TERJEMAHAN KLINKERT
}

\section{Verb Form Differences in High and Low Malay Language: Case Study of The Gospel of Matthew Klinkert Translations}

\section{Hotnida Novita Sary}

Program Pascasarjana Linguistik Bahasa dan Kebudayaan, FIB Universitas Indonesia Kampus Baru UI Depok, Jawa Barat

Pos-el: hotnida.novitasary@gmail.com

(diterima 11 Maret 2014, disetujui 8 April 2014, revisi terakhir 6 Juni 2014)

\begin{abstract}
Abstrak
Sebagai lingua franca di Nusantara, bahasa Melayu berkembang hingga memiliki ragam bahasa Melayu tinggi (BMT) dan bahasa Melayu rendah (BMR). Perbedaan ini pada akhirnya juga menimbulkan perbedaan bentuk verba. Penelitian ini akan mengkaji perbedaan bentuk verba yang terdapat dalam BMT dan BMR yang terdapat dalam Injil Matius terjemahan Klinkert. Metode yang digunakan adalah analisis dokumen. Peneliti mengunduh data dari laman sabda.org. Kedua versi Injil Matius ini kemudian dibandingkan dan dicatat satu ayat dengan ayat yang sama. Hasil pencatatan ini kemudian yang akan dianalisis. Hasil yang didapatkan dari penelitian ini adalah ragam BMT cenderung menggunakan bentuk berimbuhan, sedangkan BMR cenderung menggunakan bentuk dasar.
\end{abstract}

Kata kunci: bahasa Melayu, bahasa Melayu Rendah, bahasa Melayu tinggi, Injil, verba

\begin{abstract}
As the lingua franca of the archipelago, the Malay language grew up to have higher variance Malay (BMT) and low Malay (BMR). These differences ultimately lead to differences in the form of the verb. This study will examine different forms of the verb in BMT and BMR contained in Gospel of Matthew from Klinkert translation. The method used is the analysis of documents. Researchers download the data from the page sabda.org. Both versions of the Gospel of Matthew is then compared and recorded with the same part. The results of this recording that will be analyzed later. Results obtained from this study are likely to use a variety of forms affixes BMT, whereas BMR tend to use basic shapes.
\end{abstract}

Keywords: Malay, low Malay, high Malay, the Gospel, the verb

\section{PENDAHULUAN}

\subsection{Latar Belakang}

Bahasa Melayu digunakan di Nusantara sejak berabad-abad yang lalu. Collins (2005:8) mengatakan bahwa teks tertua dalam bahasa Melayu selesai ditulis di atas sebuah batu di Sumatera bertanggal 682 . Seiring perkembangan zaman, bangsa-bangsa asing, seperti Arab, Eropa, dan Cina, masuk ke Nusantara untuk berdagang. Sumardjo (2004:253) berpendapat bahwa hal inilah yang menyebabkan masyarakat, terutama masyarakat kota yang ramai kegiatan dagangnya, menjadi heterogen.

Ketika berkomunikasi di luar kelompoknya, mereka menggunakan bahasa yang dimengerti bersama, yaitu bahasa Melayu. Bahasa Melayu merupakan cabang bahasa lisan yang dengan sendirinya terus berubah dan berkembang berdasarkan perubahan-perubahan historisnya. Bahasa Melayu lisan inilah yang kemudian dikenal sebagai bahasa Melayu Pasar atau bahasa Melayu Rendah (selanjutnya BMR). Adapun bahasa Melayu tulis hanya dikenal di lingkungan pengguna bahasa Melayu, dan lazim disebut sebagai bahasa Melayu Riau atau bahasa Melayu Tinggi (selanjutnya BMT) (Sumardjo, 2004:253).

Bahasa Melayu merupakan bahasa resmi tulis yang digunakan di istana dan dalam bidang keagamaan. Pada saat yang sama, Bahasa Melayu 
Hotnida Novita Sary: Perbedaan Bentuk Verba pada Bahasa Melayu Tinggi dan ...

digunakan sebagai bahasa perdagangan dan bahasa interaksi. Menurut Collins (2005:33), abad 16 dapat dianggap sebagai masa peralihan saat bangsa Eropa mulai menguasai bahasa Melayu. Beberapa di antara mereka bahkan mulai menyadari potensi bahasa Melayu untuk memperluas wilayah. Salah satunya adalah usaha yang bersifat misionaristik dengan memperkenalkan agama Katolik di Nusantara.

Untuk menyebarkan agama, Alkitab dibawa masuk ke Nusantara oleh bangsa Eropa. Akan tetapi, saat itu belum semua masyarakat pribumi bisa bebas membaca Alkitab. Oleh karena itu, usaha penerjemahan Alkitab ke dalam bahasa-bahasa di Nusantara mulai dilakukan para misionaris.

Awalnya, Alkitab hanya diterjemahkan ke dalam bahasa Melayu dan Portugis. Di Nusantara, kedua bahasa ini berfungsi sebagai lingua franca, yakni bahasa yang sering digunakan dalam komunikasi antardua kelompok yang berbeda bahasa (Swellengrebel, 2006:8). Usaha penyebaran Alkitab tidak hanya berhenti pada kedua bahasa itu saja. Lembaga Alkitab Belanda (NGB) juga menerjemahkan Alkitab ke dalam berbagai bahasa di Nusantara.

Pada 1863, NGB mengangkat H.C. Klinkert menjadi penerjemah Alkitab bahasa Melayu (Swellengrebel, 2006:204-205). Klinkert (18291913) adalah misionaris Belanda yang mempunyai ketertarikan terhadap penginjilan (Swellengrebel, 2006:206). Walaupun demikian, ia adalah seorang penerjemah yang tidak menguasai bahasa alkitabiah maupun Melayu dan Sansekerta dengan baik (dalam Chambert-Loir, 2009:476). Menurut Hunt (dalam Chambert-Loir, 2009:517), ketika mempersiapkan terjemahan Alkitab, ia tinggal di Semarang sehingga pengaruh lokal jelas terlihat dalam terjemahannya. Pada 1863, NBG menerbitkan seluruh Perjanjian Baru terjemahan Klinkert dengan catatan bahwa setiap terjemahan ke dalam bahasa Melayu setempat hanyalah tindakan sementara (Swellengrebel, 2006:207).

NGB memberikan kesempatan pada Klinkert selama beberapa tahun berada di tengah-tengah orang Melayu asli (Swellengrebel, 2006:208). NGB memutuskan Klinkert pindah ke Riau dan tinggal selama dua setengah tahun (1864-1867). Selama di
Riau, ia bergaul dengan orang pribumi dan mendapatkan beberapa infoman pribumi untuk membantunya. Setelah dua setengah tahun di Riau, Klinkert kembali ke Belanda karena kesehatannya memburuk. Di Belanda, ia melanjutkan penerjemahan Alkitab ke dalam BMT. Injil Matius adalah Injil yang pertama kali ditebitkan sebagai edisi percobaan. Terjemahan Alkitabnya yang utuh terbit pada permulaan tahun 1879 dengan aksara Latin (Swellengrebel, 2006:209).

Berdasarkan buku yang ditulis A. Teeuw (1961:121-122), disebutkan Alkitab terjemahan Klinkert ditulis dalam aksara Jawi dan aksara Latin (1961:121-122). Dalam bukunya, tertulis judul Injil Perjanjian Baru terjemahan Klinkert dalam bahasa Melayu Rendah adalah Wasiat jang Baroe, Ija Itoe Segala Kitab Perdjanjian Baroe ataw Indjil Toehan Kami Jesoes Kristoes Tersalin kepada Bahasa Melajoe Rendah dengan tahun terbit 1863. Sementara itu, judul Injil Perjanjian dalam Bahasa Melayu Tinggi Klinkert adalah Wasiat jang Bharoe, Ija Itoe Segala Kitab Perdjanjian Bharoe atau Indjil Toehan Kami Isa Almasih dan tercatat terbit tahun 1870 (Teeuw, 1961:121-122). Kedua Injil Perjanjian Baru itu kini disimpan di Amsterdam, Belanda.

Injil yang pertama kali selesai diterjemahkan oleh Klinkert adalah Injil Matius, baik saat ia menggunakan bahasa Melayu di Semarang maupun saat ia menggunakan bahasa Melayu di Riau. Injil Matius dipilih oleh peneliti sebagai data dalam penelitian ini karena Injil Matius merupakan hasil terjemahan pertama dari Klinkert. Selain itu, Injil ini juga digunakan Klinkert dalam penginjilannya yang pertama di tengah-tengah masyarakat.

\subsection{Rumusan Masalah}

Masalah yang dibahas dalam penelitian ini adalah bagaimana bentuk perbedaan verba pada BMR dan BMT yang terdapat dalam Injil Matius terjemahan Klinkert. Selain itu, apakah yang menyebabkan terjadinya perbedaan tersebut. Sumber data yang peneliti gunakan dalam penelitian ini adalah Injil Matius terjemahan Klinkert yang terbit tahun 1863 (BMR) dan 1879 (BMT). 
Hotnida Novita Sary: Perbedaan Bentuk Verba pada Bahasa Melayu Tinggi dan ...

\subsection{Tujuan Penelitian}

Berdasarkan rumusan masalah di atas, tujuan penelitian ini adalah mendeskripsikan perbedaan verba yang terdapat dalam BMR dan BMT Injil Matius terjemahan Klinkert. Dengan perbedaan bentuk verba yang didapat, peneliti akan mengkaji terjadinya perbedaan bentuk verba tersebut.

\subsection{Manfaat Penelitian}

Secara teoretis, hasil penelitian ini dapat menjawab pertanyaan mengenai perbedaan bentuk verba yang terdapat dalam dua ragam bahasa Melayu, yaitu BMR dan BMT. Penelitian ini juga dapat memberikan kontribusi dan manfaat bagi ilmu pengetahuan, khususnya bagi perkembangan ilmu linguistic serta menambah wawasan masyarakat Indonesia mengenai sejarah panjang perkembangan bahasa Melayu di Nusantara.

Secara praktis, penelitian dapat bermanfaat sebagai bahan referensi dan acuan untuk melakukan penelitian mengenai perkembangan bahasa Melayu, terutama yang berkaitan dengan BMR dan BMT di masa mendatang. Oleh karena penelitian ini menggunakan teks Alkitab, yaitu Injil Matius, sebagai datanya, sedikit banyak penelitian ini memberikan pengetahuan mengenai sejarah masuknya Alkitab ke Nusantara.

\subsection{Metode Penelitian}

Penelitian ini menggunakan metode penelitian kualitatif. Dalam menganalisis data, metode ini tidak menggunakan analisis statistik, tetapi lebih banyak analisis naratif dan deskriptif. Data kualitatif mencakup deskripsi yang mendetail mengenai situasi, kegiatan, peristiwa, atau fenomena tertentu; pendapat langsung dari orang-orang yang telah berpengalaman, baik dalam pandangannya, sikapnya kepercayaan, maupun jalan pikirannya; cuplikan dari dokumen (dokumen laporan, arsip-arsip dan sejarahnya); deskripsi yang mendetail tentang sikap dan tingkah laku seseorang (Yusuf, 2007:53).

Penelitian ini merupakan studi kasus Injil Matius. Studi kasus merupakan strategi yang cocok jika pokok pertanyaan suatu penelitian berkenaan dengan how dan why, jika peneliti hanya memiliki sedikit peluang untuk mengontrol peristiwa yang akan diselidiki (Yin, 2002:1).

Teknik yang digunakan untuk mengumpulkan data dalam penelitian ini adalah teknik analisis dokumen. Oleh karena naskah fisik Injil Matius dalam BMR dan BMT tidak ditemukan, peneliti mengunduh data dari laman sabda.org. Langkah selanjutnya peneliti menandai verba yang terdapat pada BMT dengan verba yang terdapat dalam BMR di ayat yang sama. Kemudian, peneliti mendaftarkan verba tersebut ke dalam sebuah tabel yang mencakup perbedaan bentuk verba, perbedaan pembentukan, perubahan aktif-pasif. Setelah itu, peneliti menghitung kecenderungan pembentukan verba dan perbedaan yang paling sering terjadi.

Langkah selanjutnya adalah analisis data. Langkah ini dilakukan dengan melihat perbedaan pembentukan verba yang frekuensinya tinggi. Pada bagian ini, dibandingkan kalimat-kalimat dengan pembentukan yang sama sambil membandingkan perbedaan serta persamaan di antara dua verba tersebut.

\section{KERANGKA TEORI}

\subsection{Pengertian Terjemahan}

Menurut Nida dan Taber (1969:12) terjemahan adalah upaya mereproduksi serta mengungkapkan kembali pesan yang terkandung dalam bahasa sumber ke bahasa sasaran dengan menggunakan padanan yang tepat. Sebuah terjemahan harus mengutamakan makna dan pesan yang ingin disampaikan sebuah teks. Penerjemahan dapat diartikan sebagai upaya penyampaian kembali pesan dalam konstruksi suatu bahasa ke dalam konstruksi bahasa lain dengan padanan yang tepat.

Menurut Munday (2001:4), terjemahan adalah sesuatu yang mengacu pada bidang subjeknya secara umum, yaitu produk (teks yang telah diterjemahkan) atau proses (kegiatan menerjemahkan). Kegiatan penerjemahan selalu dihadapkan pada dikotomi antara mempertahankan bentuk atau mementingkan pesan. Para ahli sepakat bahwa yang dipentingkan adalah pesan. Bentuk - seperti struktur bahasa-digunakan sebagai alat penyampai pesan. Dengan demikian, bentuk boleh berubah, tetapi pesannya tidak. Respati (2007:11) menyebutkan bahwa ada beberapa terjemahan yang setia pada bentuk teks bahasa 
Hotnida Novita Sary: Perbedaan Bentuk Verba pada Bahasa Melayu Tinggi dan ...

sumber, seperti penerjemahan kitab suci dan teks hukum.

\subsection{Periode Perkembangan Bahasa Melayu}

Kridalaksana menggunakan pendekatan sejarah untuk melihat perkembangan bahasa Melayu, yaitu menggunakan bukti-bukti tertulis. Kridalaksana (1991:5) membagi periodisasi sejarah bahasa Melayu atas (1) bahasa Melayu Kuna yang meliputi kurun abad ke-7 sampai abad ke-14; (2) bahasa Melayu Tengahan yang mencakup bahasa Melayu Klasik dalam kurun waktu abad ke-14 sampai abad ke-18; (3) bahasa Melayu Peralihan yang mencakup kurun abad ke-19; (4) bahasa Melayu Baru yang digunakan sejak awal abad ke-20.

Pengetahuan mengenai awal bahasa Melayu dapat diperoleh dari batu bersurat atau bahan lain yang tersebar di Jawa Tengah, Lampung, Sumatra Selatan, Jambi, Bangka, dan Sumatra Selatan. Pengetahuan bahasa Melayu Tengahan dapat diketahui dari suratsurat, naskah perjanjian, dan karya-karya sastra klasik (Kridalaksana, 1991:6-7). Akan tetapi, Kridalaksana tidak menyebutkan di mana dapat didapatkan bahan tertulis bahasa Melayu Peralihan dan bahasa Melayu Baru.

Berdasarkan pembagian yang dilakukan oleh Harimurti, Injil Matius terjemahan Klinkert yang digunakan dalam penelitian ini termasuk periode Melayu Peralihan karena ditulis pada 1863 dan 1879.

\subsection{Pendapat Para Ahli mengenai BMR dan BMT}

Bahasa Melayu juga dapat diklasifikasikan menurut ragam yang digunakan dalam masyarakat. Pada bagian ini ditampilkan beberapa pendapat ahli bahasa Melayu mengenai penamaan "tinggi" dan "rendah" dalam bahasa Melayu.

Menurut Gerth van Wijk (1889), bahasa Melayu telah tersebar di seluruh Kepulauan Hindia Timur sebagai bahasa yang digunakan oleh orang asing dengan penduduk setempat. Bahasa Melayu ini pada akhirnya berubah dengan memungut kata, ungkapan, dan bentuk bahasa tempat bahasa Melayu dibawa masuk. Van Wijk menyimpulkan bahwa BMR adalah bahasa yang digunakan para pendatang dengan memungut kata, ungkapan, atau bentuk bahasa lain ke dalam bahasa Melayu. Adapun, BMT adalah bahasa yang digunakan penutur asli dengan menggunakan kata, ungkapan, atau bentuk bahasa Melayu yang asli tanpa pengaruh asing.

Sementara itu, J.J. de Hollander (1893) berpendapat bahwa pemisahan antara BMR dan BMT tidak pantas dilakukan karena keduanya merupakan bahasa yang sama dengan bahasa istana, hanya saja salah satunya kurang murni dibanding yang lain dari segi tata bahasa dan lebih banyak pengaruh kata-kata asing.

Ahli lain, Ch. A. van Ophuijsen (1915), berpendapat bahwa orang Eropa membedakan bahasa Melayu atas BMT dan BMR. Yang mereka maksudkan bukanlah perbedaan antarjenis bahasa "tinggi" dan "rendah" seperti yang dikenal pada masyarakat Jawa. Bagi orang Eropa, BMT adalah bahasa yang dituturkan dan ditulis oleh orang Melayu (karena itu dapat disebut bahasa pustaka Melayu). Adapun BMR (disebut juga Melayu pesisir, Melayu pasar, Melayu tangsi) adalah satu ragam bahasa yang terbentuk dari kalimat yang terdiri atas rangkaian kata Melayu atau yang dianggap Melayu, tanpa memperhitungkan ciri khas bahasa Melayu, atau yang sering menyalahi kaidah bahasa Melayu.

Menurut Spat (1989), bahasa katjauan atau katjoekan, bahasa pekan atau pasar adalah bahasa yang terjadi karena pergaulan orang Melayu dengan orang-orang asing. Selain itu, terdapat pula ragam bahasa Melayu kesusastraan yang digunakan di berbagai karya sastra, baik prosa atau puisi, baik karya asli maupun saduran karya asing. Bahasa Melayu kesusastraan ditulis dalam abjad Arab yang telah berubah karena pengaruh bahasa Persia. Sama seperti bahasa pasar, bahasa kesusastraan memang tidak bebas dari pengaruh asing, tetapi mampu menjaga bahasa dari kerusakan, dalam arti tidak menyalahi kaidah-kaidah bahasa Melayu. Spat juga berpendapat bahasa lisan sehari-hari bersifat sangat padat, sedikit kata tetapi sudah mampu mengungkapkan arti yang luas. Adapun bahasa yang digunakan dalam sastra Melayu, khususnya yang lebih tua, cenderung panjang dan berbelit.

J.L. Swellengrebel (2006) membedakan bahasa Melayu atas empat ragam, yaitu (a) bahasa Melayu sebagai bahasa daerah asli; (b) bahasa Melayu yang 
menyebar lebih luas dan berpedoman pada bentuk tertulis bahasa daerah asli; (c) bahasa Melayu lokal sebagai bahasa yang telah merakyat dan menjadi lingua franca; (d) bahasa Melayu pasar, yaitu bagian dari ragam (c) yang paling sederhana dan paling mudah "diblesterkan" dan hanya digunakan dalam kontak terbatas. Adapun, (b) dan kadang-kadang (a) lazim disebut "Melayu tinggi", sedangkan (c) dan kadang-kadang (d) disebut "Melayu rendah".

Dari pendapat para ahli di atas, terdapat beragam istilah mengenai BMR dan BMT. Akan tetapi, seperti yang dikatakan Sutan Takdir Alisjahbana (1957:45), penyebutan bahasa Melayu Tinggi dan bahasa Melayu Rendah adalah nama yang paling umum. Dua istilah tersebut memang tidak dapat didefinisikan dengan baik secara linguistik, tetapi pola ekstrem keduanya sudah jelas. Oleh sebab itu, penelitian ini menggunakan istilah bahasa Melayu Tinggi dan bahasa Melayu Rendah untuk menyebut dua ragam bahasa Melayu.

\subsection{Pembagian dan Bentuk Verba}

Pada bagian ini, peneliti memaparkan pengertian serta bentuk-bentuk verba yang dilakukan oleh para ahli. Pemaparan mengenai verba dan bentukbentuknya menurut para ahli ini disusun menurut urutan tahun terbit.

a. Menurut van Wijk (1889), verba adalah kata yang tidak mempunyai bentuk tasrifnya dalam bahasa Melayu, artinya tidak dikenalnya berbagai bentuk untuk modus, kala, persona, atau jumlah.

b. Menurut de Hollander (1893), verba adalah kata pokok dalam predikat, yaitu atribut, yang tidak memiliki bentuk khas.

c. Menurut Ophuijsen (1915), verba adalah setiap kata yang dapat ditasrifkan, artinya kata yang mampu mengadakan ikatan yang tidak terputuskan dengan pronomina persona.

d. Menurut Slametmuljana (1917), perkataan pekerjaan adalah perkataan yang menyatakan perbuatan pokok kalimat, menyatakan perubahan hal atau barang yang namanya disebutkan oleh pokok kalimat, serta menyatakan hal pokok kalimat. e. Menurut Winckel (1944), verba dalam bahasa Melayu adalah kata yang tidak mengalami perubahan suasana, waktu, angka, atau orang.

f. Menurut Wojowasito (1970), verba adalah jenis kata yang mempunyai ciri-ciri: lazim menduduki fungsi predikat, lazim mengikuti subjek dan mendahului objek, dapat diikuti oleh preposisi, dapat digunakan untuk perintah, dapat mengalami perubahan genus (aktif dan pasif), serta dapat didahului oleh kata-kata boleh, akan, hendak, sedang, telah, sambil.

g. Menurut Kridalaksana (1999), sebuah kata dapat dikatakan berkategori verba dapat diketahui dari perilakunya dalam frase, yakni dalam hal kemungkinan satuan tersebut didampingi partikel tidak dalam konstruksi dan dalam hal tidak dapat didampingi dengan partikel $d i$, ke, dari, atau dengan partikel sangat, lebih, atau agak.

Dari uraian itu, dapat dirumuskan verba dalam bahasa Melayu adalah kelas kata yang tidak mempunyai bentuk tasrif dan lazim menduduki fungsi predikat, mengikuti subjek dan mendahului objek dalam sebuah kalimat. Sebuah verba dapat dikenali dari kemungkinan satuan itu didampingi partikel tidak dalam konstruksi dan dalam hal tidak dapat didampingi dengan partikel $d i, k e$, dari, atau dengan partikel sangat, lebih, atau agak.

Berdasarkan teori yang dikemukakan para ahli di atas, penelitian ini akan menggunakan teori Kridalaksana sebagai landasan teori karena lebih sistematis dan telah mencakup serta merangkum keseluruhan teori-teori yang para ahli bahasa Melayu lainnya. Dengan demikian, pembentukan verba yang digunakan dalam penelitian ini adalah sebagai berikut.

a. Verba dasar, yaitu verba yang berupa morfem dasar bebas dan menyatakan perbuatan, lebih-lebih yang menyatakan gerak atau istirahat, bertindak tanpa perubahan sedikit pun, contoh: doedoek, bangoen, baring.

b. Verba turunan, yaitu verba yang mendapat afiksasi sebagai pembentuk verba, unsur formatif ini dapat berbentuk prefiks, sufiks, dan konfiks. Adapun afiks pembentuk verba dapat berbentuk prefiks, sufiks, dan konfiks. 
Hotnida Novita Sary: Perbedaan Bentuk Verba pada Bahasa Melayu Tinggi dan ...

Berdasarkan hubungan verba dengan nomina, verba dapat dibagi menjadi:

a) aktif ditandai dengan afiks me- dan ber-;

b) pasif ditandai dengan afiks di-, ter-, dan ke-an.

Selain bentuk-bentuk tersebut, terdapat partikel penegas -lah. Partikel ini berfungsi untuk memberikan tekanan, menarik perhatian, sekaligus memperhalus perintah atau suruhan.

\section{PEMBAHASAN}

Afiks-afiks pembentuk verba turunan, menurut Kridalaksana (2007), adalah: (1) prefiks me-, (2) simulfiks N, (3) prefiks ber-, (4) konfiks ber-(R), (5) prefiks per-, (6) prefiks ter-, (7) prefiks ke-, (8) sufiks -in, (9) kombinasi me-i, (10) kombinasi di-i, (11) kombinasi me-kan, (12) kombinasi afiks memper-, (13) kombinasi afiks diper-, (14) kombinasi afiks memper-kan, (15) kombinasi afiks diper-kan, (16) kombinasi afiks N-in, (17) konfiks ber-an, (18) konfiks ber-(R)-an, (19) konfiks ber-kan, (20) konfiks ke-an, (21) kombinasi afiks ter-R, (22) kombinasi afiks per-kan, (23) kombinasi afiks per-i, serta (24) kombinasi afiks ber-(R).

Berdasarkan teori tersebut, peneliti menemukan sejumlah verba yang termasuk dalam afiks pembentuk verba yang dikemukakan Kridalaksana. Afiks pembentuk verba tersebut yang terdapat pada BMR adalah sebagai berikut.

1. me-, seperti: mendapet;

2. N, seperti: nganteh;

3. ber-, seperti: bertrejak;

4. ber-(R), seperti: bergirang-girang;

5. ter-, seperti: terhantar;

6. ke-, seperti: katemoe;

7. me-i, seperti: mendjalani;

8. di-i, seperti: digenepi;

9. me-kan, seperti: meroekoenken;

10. diper-kan, seperti: dipermandiken;

11. ber-an, seperti: berkasihan;

12. ber-kan, seperti: beranaken;

13. ke-an, seperti: kedapetan;

14. ter (R), seperti: tersapoe-sapoe;

15. ber- (R), seperti: berbantah-bantah.

Dengan demikian, afiks pembentuk verba Kridalaksana yang tidak terdapat dalam BMR adalah
(1) per-, (2) -in, (3) memper-, (4) diper-, (5) memperkan, (6) N-in, (7) ber-R-an, (8) per-kan, dan (9) per-i.

Sebaliknya, dalam data BMR peneliti menemukan sejumlah pembentuk verba yang tidak termasuk dalam afiks pembentuk verba seperti yang dikatakan oleh Kridalaksana. Afiks pembentuk verba tersebut adalah sebagai berikut.

1. ken, seperti: besarken;

2. di-, seperti: diboenoeh;

3. di-ken, seperti: dikaloewarken;

4. - $i$, seperti: ampoeni;

5. VD (R), seperti: pake-pake;

6. $\quad$ di-(R), seperti dibagi-bagi;

7. di-(R)-ken, seperti: dipetjah-petjahken;

8. di-(R)-i, seperti: dikata-katai;

9. ke-i, seperti: ketawai;

10. -an, seperti: tidoeran;

11. ter-ken, seperti: tersiarken;

12. (R)+-i, seperti: marah-marahi.

Hal yang sama juga terjadi pada BMT. Peneliti menemukan sejumlah afiks pembentuk verba yang terdapat dalam teori yang dikemukakan Kridalaksana. Afiks pembentuk verba tersebut adalah sebagai berikut.

1. me-, seperti: mengandoeng;

2. ber-, seperti: berpaling;

3. ber-R, seperti: bersangka-sangka;

4. per-, seperti: perboewat;

5. ter-, seperti: teraniaja;

6. me-i, seperti: mengoendjoengi;

7. di-i, seperti: diperiksai;

8. me-kan, seperti: memikirkan;

9. memper-, seperti: memperboewat;

10. memper-kan, seperti: memperdamaikan;

11. diper-kan, seperti: diperbinikan;

12. ber-an, seperti: bertentangan;

13. ber-kan, seperti: beralaskan;

14. ke-an, seperti: kasoedahan;

15. ter-R, seperti: tertjengang-tjengang;

16. per-kan, seperti: pertoendjoekkan;

17. ber-R, seperti: berkata-kata.

Dengan demikian, afiks pembentuk verba yang tidak ditemukan pada BMT adalah (1) N, (2) ke-, (3) -in, (4) diper-, (5) N-in, (6) ber-R-an, (7) per-i. 
Hotnida Novita Sary: Perbedaan Bentuk Verba pada Bahasa Melayu Tinggi dan ...

Sebaliknya, dalam data BMT ditemukan sejumlah pembentuk verba yang tidak termasuk dalam afiks pembentuk verba seperti yang diungkapkan oleh Kridalaksana. Afiks pembentuk verba tersebut adalah sebagai berikut.

1. berka-an, seperti: berkasoekaan;

2. di-(R), seperti: dipidjak-pidjak;

3. di-(R)-kan, seperti: dipetjah-petjahkannja;

4. di-an, seperti: disoeroehannja;

5. di-i, seperti: didjalaninja;

6. di-kan, seperti: dibakarkan;

7. dike-i, seperti: diketahoei;

8. ke-i, seperti: ketahoei;

9. me-(R), seperti: memilih-milih;

10. me-(R) -kan, seperti: mentjarik-tjarik;

11. pe-an, seperti: pemindahan;

12. pe-i, seperti: peladjarilah;

13. per-kan, seperti: persembahkanlah;

14. ter-kan, seperti: terpadamkan;

15. (R)-i, seperti: oelang-oelangi;

16. (R), seperti: behagi-behagilah;

17. $-i$, seperti: ampoenilah;

18. -kan, seperti: karoeniakan.

Perbedaan verba antara BMR dan BMT tidak hanya terdapat pada perbedaan afiks pembentuk verba, tetapi juga pada perbedaan leksem. Contoh: melihat (BMR)-diketahoei (BMT) dan djatoh (BMR)terdjoenlah (BMT), serta perbedaan yang terjadi dalam tataran frase verbal, seperti djadi roekoen (BMR)-berdamai (BMT) dan kasih inget (BMR)menasihatkan (BMT). Perbedaan seperti ini akan dibahas pada subbab-subbab berikutnya.

\subsection{Perbedaan Bentuk Verba dalam BMR dan BMT}

Selain terdapat perbedaan morfologis, terdapat juga perbedaan penggunaan leksem antara verba BMR dan BMT. Berdasarkan penghitungan, peneliti menemukan 936 verba yang mencakup perbedaan morfologis dengan leksem yang sama dan perbedaan leksem yang berbeda. Jumlah verba dan persebaran morfologis dapat dilihat pada tabel berikut.
Tabel 1

\begin{tabular}{|c|c|c|}
\hline & Jumlah Verba & $\%$ \\
\hline $\begin{array}{c}\text { Verba dengan leksem yang } \\
\text { sama }\end{array}$ & 450 & 48.08 \\
\hline $\begin{array}{c}\text { Verba dengan leksem yang } \\
\text { berbeda }\end{array}$ & 486 & 51.92 \\
\hline$\Sigma$ & $\mathbf{9 3 6}$ & $\mathbf{1 0 0 . 0 0}$ \\
\hline
\end{tabular}

Berdasarkan tabel di atas, dapat diketahui bahwa dari total 936 perbedaan verba, $450(49,08 \%)$ di antaranya adalah perbedaan morfologis verba dengan leksem yang sama, sedangkan 486 (51,92\%) lainnya adalah perbedaan morfologis verba dengan leksem yang berbeda. Dengan demikian, dapat dilihat bahwa perbedaan morfologi verba dengan verba yang sama dan berbeda jumlahnya hampir berimbang. Hal ini menunjukkan bahwa perbedaan antara BMR dan BMT tidak hanya sebatas pada perbedaan proses pembentukan kata, tetapi juga menyangkut masalah pemilihan kata.

Pada Tabel 2, peneliti melakukan penghitungan penggunaan verba dasar (VD) dan verba berafiks (VB) yang terdapat pada BMR. Bentuk verba pada BMR mencakup bentuk VD, seperti: bangoen, poengoet, kasih. Adapun, bentuk VB pada BMR seperti: mengkeret, berlapar, dan diboeneh. Tabel penghitungan VD dan VB pada BMR adalah sebagai berikut.

\section{Tabel 2}

\begin{tabular}{|c|c|c|}
\hline & BMR & $\%$ \\
\hline VD & 439 & 45,16 \\
\hline VB & 532 & 54,83 \\
\hline
\end{tabular}

Berdasarkan tabel di atas, dapat dilihat bahwa persentase bentuk VB dan VD hampir seimbang. Bentuk VB sedikit lebih tinggi dibandingkan bentuk VD, yaitu sebanyak 54,83\% sementara VD sebanyak $45,16 \%$. Hal ini selain menunjukkan bahwa bentuk verba dasar cukup sering digunakan, juga memperlihatkan bahwa BMR tidak konsisten menggunakan bentuk verba dasar atau verba berimbuhan.

Peneliti juga melakukan penghitungan penggunaan VD dan VB pada BMT. Bentuk VD pada BMT juga mencakup bentuk VD yang dilekati klitik sebagai penanda pelaku. Contoh bentuk VD pada BMT adalah sahoet, datang, dan koehamboer. Adapun, bentuk VB 
Hotnida Novita Sary: Perbedaan Bentuk Verba pada Bahasa Melayu Tinggi dan ...

pada BMT seperti: membajar, ditoeroetnja, dan terloepalah. Tabel penghitungan VD dan VB pada BMT adalah sebagai berikut.

Tabel 3

\begin{tabular}{|c|c|c|}
\hline & BMT & \% \\
\hline VD & 98 & 10,28 \\
\hline VB & 873 & 89,71 \\
\hline
\end{tabular}

Berdasarkan tabel tersebut, dapat dilihat bahwa berbeda dengan BMR, bentuk VB pada BMT sangat tinggi (sebanyak 89,71\%) dibandingkan bentuk VD (sebanyak 10,28\%). Selain menunjukkan bahwa kecenderungan penggunaan bentuk VB sangat tinggi, hal ini juga memperlihatkan bahwa BMT lebih konsisten menggunakan bentuk VB dibandingkan BMR.

\subsection{Perbedaan Morfologis Verba dengan}

Leksem yang Sama dalam BMR dan BMT

Dalam data ditemukan 450 (100\%) perbedaan morfologis dengan leksikal yang sama dengan 139 proses morfologis. Dari 139 proses morfologis tersebut, tidak semua proses dianalisis. Peneliti hanya membahas serta menguraikan pola pembentukan yang frekuensinya lebih dari sepuluh. Pola-pola perbedaan tersebut didaftarkan sebagai berikut.
Tabel 4

\begin{tabular}{|l|l|l|c|c|}
\hline No. & BMR & BMT & Frek. & \% \\
\hline 1. & VD & VD+-lah & 47 & 10.44 \\
\hline 2. & VD & di-+VD & 35 & 7.78 \\
\hline 3. & VD & me-+VD & 33 & 7.33 \\
\hline 4. & VD & ber-+VD & 16 & 3.56 \\
\hline 5. & VD+-ken & me-+VD+-kan & 22 & 4.89 \\
\hline 6. & VD+-ken & VD+-kanlah & 11 & 2.44 \\
\hline 7. & VD+-ken & di-+VD+-kan & 11 & 2.44 \\
\hline 8. & me-+VD & di-+VD & 32 & 7.11 \\
\hline 9. & me-+VD & VD & 11 & 2.44 \\
\hline 10. & me-+VD+-ken & di-+VD+-kan & 11 & 2.44 \\
\hline
\end{tabular}

Berdasarkan tabel tersebut, dapat dilihat bahwa penggunaan VD pada BMR dan VB pada BMT mendominasi empat pola perbedaan yang memiliki frekuensi tertinggi. Kesepuluh pola perbedaan verba ini akan diuraikan satu persatu. Selain itu, peneliti juga menyertakan lima contoh kalimat pada setiap pola perbedaan yang dikutip secara acak dari data. Analisis dan uraian kesepuluh pola perbedaan verba terdapat pada uraian berikut.

\subsubsection{VD $\rightarrow$ VD+-lah}

Perbedaan pembentukan VD pada BMR dan VB ditambah partikel -lah pada BMT adalah pembentukan yang paling banyak ditemukan. Pada data, perbedaan pola pembentukkan ini ditemukan sebanyak 47 kata $(10,44 \%)$. Beberapa contoh perbedaan ini terdapat pada beberapa contoh berikut.

Tabel 5

\begin{tabular}{|l|l|l|l|l|}
\hline No. & $\begin{array}{c}\text { pasal: } \\
\text { ayat }\end{array}$ & \multicolumn{1}{|c|}{ BMR } & \multicolumn{1}{c|}{$\begin{array}{l}\text { Pola Urutan } \\
\text { Kata }\end{array}$} \\
\hline 1. & $2: 2$ & $\begin{array}{l}\text {...dan kita orang soedah dateng maoe } \\
\text { menjembah-soedjoed sama Dia. }\end{array}$ & $\begin{array}{l}\text {...maka datanglah kami ini hendak } \\
\text { menjembah dia. }\end{array}$ & SVK-VSK \\
\hline 2. & $5: 1$ & Jesoes naik di-atas satoe goenoeng... & ...naiklah ija ka-atas saboewah boekit... & SVK-VSK \\
\hline 3. & $2: 13$ & $\ldots$ dan ambil itoe anak... & ...ambillah kanak-kanak itoe... & VO-VO \\
\hline 4. & $7: 25$ & Maka hoedjan deres toeroen... & $\begin{array}{l}\text { Toendjoeklah kapadakoe oewang oepeti } \\
\text { itoe. }\end{array}$ & VKO-VKO \\
\hline 5. & $22: 19$ & Toendjoek sama Akoe itoe dinar beja. & & \\
\hline
\end{tabular}

Kelima verba dalam kalimat di atas-baik BMR maupun BMT_-berkedudukan sebagai predikat. Bila dilihat dari segi pola urutan kata (S-V), pada kalimat (1) BMR berpola urutan S-V, yaitu subjek (kita orang) yang mendahului verba (dateng), sedangkan BMT berpola V-S, yaitu verba (datanglah) mendahului subjek (kami ini). Hal yang sama juga terjadi pada kalimat (2), BMR berpola $S-V$ sedangkan BMT berpola V-S. Kalimat (3), baik BMR maupun BMT tidak mempunyai subjek. Pola urutan kalimat pada BMR dan BMT tidak berbeda, yakni V-O. Berbeda dengan kalimat (1), (2), pada kalimat (4) dan (5) tidak ada perubahan pola urutan pada kalimat BMR dan BMT. Pada contoh (4), baik BMR maupun 
Hotnida Novita Sary: Perbedaan Bentuk Verba pada Bahasa Melayu Tinggi dan ...

BMT, berpola S-V, sedangkan pada contoh (5) keduanya berpola V-K-O. Dengan demikian terdapat kecenderungan verba berpartikel -lah mendahului subjek sedangkan VD mengikuti subjek.

Menurut Alwi, dkk (2003:308), partikel -lah digunakan dalam kalimat imperatif yang berfungsi untuk menghaluskan perintah. Pada kalimat deklaratif, partikel -lah juga digunakan untuk memberikan ketegasan. Sementara itu, menurut van Wijk (1985:108), partikel penegas -lah berfungsi untuk menonjolkan-atau dengan kata lain memfokuskan - kata yang diikuti partikel -lah. Selain itu, partikel -lah juga berfungsi sebagai penanda aspek, yaitu untuk menerangkan suatu pekerjaan, peristiwa, keadaan, atau sifat sedang berlangsung, sudah selesai, belum selesai, atau mulai berlangsung.
Pada kelima kalimat di atas, beberapa fungsi partikel -lah tersebut dapat ditemukan. Pada kalimat (1) dan (2), partikel -lah berfungsi untuk menonjolkan atau memfokuskan verba (datanglah dan naiklah) dibandingkan unsur yang lain. Pada kalimat (3) dan (5), partikel -lah yang melekat pada verba (ambillah dan toendjoeklah) berfungsi untuk menghaluskan perintah. Pada kalimat (4), partikel -lah yang melekat pada verba (toeroenlah) berfungsi sebagai penanda aspek peristiwa (hoedjan) sedang berlangsung.

\subsubsection{VD $\rightarrow d i-+\mathrm{VD}$}

Jumlah penggunaan VD pada teks BMR dan penggunaan afiks $d i$ - ditambah VD pada teks BMT cukup tinggi. Pada data, perbedaan ini ditemukan sebanyak 35 kata (7,78\%). Berikut ini adalah beberapa contoh perbedaan penggunaan VD pada BMR dan penggunaan afiks di- ditambah VD.

Tabel 6

\begin{tabular}{|c|c|c|c|c|}
\hline No. & $\begin{array}{c}\text { pasal: } \\
\text { ayat }\end{array}$ & BMR & BMT & $\begin{array}{c}\text { Pola Urutan } \\
\text { Kata }\end{array}$ \\
\hline 1. & $6: 2$ & $\begin{array}{l}\text {...seperti orang poera-poera boewat didalem } \\
\text { mesdjid-mesdjid }\end{array}$ & $\begin{array}{l}\text {...saperti diboewat olih orang poera-poera } \\
\text { dalam masdjid }\end{array}$ & SVK-VK \\
\hline 2. & $2: 7$ & Herodes panggil itoe orang alim... & $\begin{array}{l}\text { dipanggil olih radja Herodis akan segala } \\
\text { madjoesi itoe... }\end{array}$ & SVO-VKS \\
\hline 3. & $19: 7$ & $\begin{array}{l}\text { nabi Moesa soedah pesen kasih soerat } \\
\text { talak... }\end{array}$ & $\begin{array}{l}\text { dipesan olih Moesa memberikan soerat } \\
\text { talak... }\end{array}$ & SVO-VKS \\
\hline 4. & $20: 3$ & dia lihat lain orang... & dilihatnja orang lain... & SVO-V(K)S \\
\hline 5. & $9: 25$ & ...serta pegang tangannja & ...laloe dipegangnja tangannja & VO-V(K)S \\
\hline
\end{tabular}

Dari lima kalimat di atas, verba-baik BMR maupun BMT-berkedudukan sebagai predikat. Bentuk verba yang terdapat pada BMR adalah verba aktif sedangkan pada BMT adalah verba pasif. Bila dilihat dari pola urutan kata, kalimat (1), pada BMR verba (boewat) mengikuti subjek (orang poerapoera) dan diikuti keterangan (didalem mesdjidmesdjid), sedangkan pada BMT verba (diboewat) berada di depan keterangan (olih orang poera-poera dalam masdjid). Jadi, BMR berpola urutan S-V-K sedangkan BMT berpola urutan V-K. Kalimat (2), pada BMR subjek (Herodes) berada di depan verba (panggil) dan objek (itoe orang alim), sedangkan pada BMT, verba (dipanggil) berada di depan keterangan (olih radja Herodis) dan subjek (akan segala madjoesi itoe). Oleh karena itu, BMR berpola urutan S-V-O, sedangkan BMT berpola urutan V-KS. Hal yang sama juga terjadi pada kalimat (3), BMR berpola urutan S-V-O sedangkan BMT berpola urutan $\mathrm{V}-\mathrm{K}-\mathrm{S}$

Contoh (4), subjek (dia) pada BMR diikuti verba (lihat) dan objek (lain orang) sehingga berpola S-VO. Pada teks BMT, verba (dilihat) — serta keterangan pelaku yang melekat pada verba (-nja) — dan subjek (orang lain) sehingga berpola V(K)-S. Pada contoh terakhir, pada BMR verba (pegang) berada di depan objek (tangan-sehingga berpola V(K)-O. Pada BMT, subjek (tangannja) mengikuti verba (dipegang)—dan keterangan pelaku yang melekat pada verba ( $n j a)$ sehingga berpola $\mathrm{V}(\mathrm{K})-\mathrm{S}$.

\subsubsection{VD $\rightarrow m e-+V D$}

Frekuensi penggunaan verba dasar di BMR dan verba berafiks me- di BMT sebanyak 33 kata (7,33\%). Hal ini menunjukkan kecenderungan penggunaan afiks me- pada verba BMT dan bentuk 
Hotnida Novita Sary: Perbedaan Bentuk Verba pada Bahasa Melayu Tinggi dan ...

dasar di BMR cukup tinggi. Contohnya sebagai berikut.

Tabel 7

\begin{tabular}{|l|l|l|l|l|}
\hline No. & $\begin{array}{c}\text { pasal: } \\
\text { ayat }\end{array}$ & \multicolumn{1}{|c|}{ BMR } & \multicolumn{1}{|c|}{ BMT } & \multicolumn{1}{|c|}{$\begin{array}{c}\text { Pola Urutan } \\
\text { Kata }\end{array}$} \\
\hline 1. & $2: 8$ & ...dan kaloe soedah dapet sama dia... & ..maka apabila kamoe mendapat dia... & VK-SVO \\
\hline 2. & $2: 13$ & $\begin{array}{l}\text {...karna Herodes nanti tjari itoe anak maoe } \\
\text { memboenoeh sama dia. }\end{array}$ & $\begin{array}{l}\text { karena Herodis mentjehari djalan hendak } \\
\text { memboenoeh kanak-kanak itoe. }\end{array}$ & SVOK-SVOK \\
\hline 3. & $5: 42$ & ...orang maoe pindjem dari kamoe. & $\begin{array}{l}\text {..orang hendak memindjam barang soeatoe } \\
\text { kapadamoe... }\end{array}$ & SVK-SVOK \\
\hline 4. & $21: 23$ & $\begin{array}{l}\text { Dengan koewasa apa angkau boewat segala } \\
\text { perkara ini? }\end{array}$ & $\begin{array}{l}\text { Dengan koewasa apa garangan engkau } \\
\text { memboewat segala perkara ini... }\end{array}$ & KSVO-KSVO \\
\hline 5. & $9: 3$ & Ini orang berkata hoedjat. & Bahwa orang ini menghoedjat Allah. & SVPel.-SVO \\
\hline
\end{tabular}

Kelima VD dan VB pada tabel berkedudukan sebagai predikat. Bila dilihat dari segi pola urutan kata, kalimat (1), BMR terdapat verba (dapet) yang diikuti keterangan (sama dia). Adapun pada BMT subjek (kamoe) diikuti verba (mendapat) dan keterangan (dia). Pada kalimat (2), tidak ada perbedaan pola urutan kata antara BMR dan BMT, keduanya berpola urutan S-V-O-K. Selain itu, baik BMR maupun BMT, subjek (Herodes-Herodis) mendahului verba dan didahului objek (itoe anakdjalan). Hal yang sama juga terjadi pada kalimat (4) yaitu tidak ditemukan perbedaan pola urutan antara BMR dan BMT, keduanya berpola urutan K-S-V-O.

Pada kalimat (3), teks BMR verba (maoe pindjem) mengikuti subjek (orang) dan diikuti keterangan (dari kamoe) sehingga berpola urutan S-V-K. Adapun, pada teks BMT subjek (orang) diikuti verba (hendak memindjam), objek (barang soeatoe) dan keterangan (kapadamoe) sehingga berpola S-V-O-K. Pada kalimat (5), menghoedjat pada BMT yang berfungsi sebagai verba berbeda dengan hoedjat pada BMR yang berfungsi sebagai pelengkap. Fungsi verba pada BMR diduduki verba berkata. Adapun bila dilihat dari pola urutan kata, BMR berpola S-V-Pel. sedangkan BMT berpola S-V-O.

Dari kelima kalimat tersebut, dapat dilihat bahwa penambahan afiks me- pada BMT cenderung tidak berbeda dengan penggunaan VB pada BMR, yaitu berpola $\mathrm{S}-\mathrm{V}(\mathrm{O})$. Hal ini berbeda dengan pola VD+ -lah pada BMT dalam pembahasan sebelumnya. Penambahan partikel -lah cenderung mengubah pola urutan dengan menempatkan verba di depan subjek.

\subsubsection{VD $\rightarrow$ ber-+VD}

Bentuk VD pada BMR dan ber- ditambah VD yang terdapat pada BMT cukup besar, yaitu 16 kata $(3,56 \%)$. Walaupun frekuensi bentuk pola ini tidak sebanyak pola VD pada BMR dan me-+VD pada BMT, pola ini cukup sering berulang. Hal ini dapat dilihat pada tabel berikut.

Tabel 8

\begin{tabular}{|l|l|l|l|l|}
\hline No. & $\begin{array}{c}\text { pasal: } \\
\text { ayat }\end{array}$ & \multicolumn{1}{|c|}{ BMR } & \multicolumn{1}{|c|}{ BMT } & \multicolumn{1}{|c|}{$\begin{array}{c}\text { Pola Urutan } \\
\text { Kata }\end{array}$} \\
\hline$(1)$ & $3: 9$ & $\begin{array}{l}\text { Allah koewasa mendjadiken anak } \\
\text { Ibrahim... }\end{array}$ & $\begin{array}{l}\text { Allah berkoeasa djoega mengadakan anak-anak } \\
\text { bagai Iberahim... }\end{array}$ & SVPel.-SVPel. \\
\hline$(2)$ & $5: 46$ & $\begin{array}{l}\text { Boekan pentjoke boewat sabagitoe } \\
\text { djoega? }\end{array}$ & $\begin{array}{l}\text { Boekankah pemoengoet tjoekai pon berboewat } \\
\text { demikian? }\end{array}$ & SVO-SVPel. \\
\hline$(3)$ & $26: 63$ & Tetapi Jesoes diam sadja. & Tetapi Isa berdiam djoega dirinja. & SVK-SVK \\
\hline$(4)$ & $24: 43$ & ...dia djaga & ..ija berdjaga & SV-SV \\
\hline$(5)$ & $6: 1$ & $\begin{array}{l}\text {...kamoe djangan boewat } \\
\text { sedekahmoe... }\end{array}$ & ...djangan kamoe berboewat kabadjikanmoe... & SVO-SVPel. \\
\hline
\end{tabular}

Berdasarkan lima verba dalam kalimat di atas, dapat dilihat bahwa verba berkedudukan sebagai predikat. Dalam contoh (1), pada BMR subjek (Allah) diikuti verba (koewasa) dan pelengkap (mendjadiken anak Ibrahim), pada BMT subjek (Allah) diikuti verba (berkoewasa) dan pelengkap (djoega mengadakan anak-anak bagai Iberahim). Jadi, baik BMR maupun BMT berpola urutan S-V-Pel. Dalam 
Hotnida Novita Sary: Perbedaan Bentuk Verba pada Bahasa Melayu Tinggi dan ...

contoh (2), pada BMR subjek (pentjoke) diikuti verba (boewat) dan objek (sabagitoe djoega), dan pada BMT, subjek (pemoengoet tjoekai pon) diikuti verba (berboewat) dan pelengkap (demikian). Oleh karena itu, BMR berpola S-V-O, sedangkan BMT berpola urutan S-V-Pel. Pada kalimat (3), verba pada BMR dan BMT adalah verba intransitif, yaitu verba tidak membutuhkan kehadiran objek, sehingga dalam hal pola urutan keduanya tidak berbeda S-V-K.

Pada contoh (4) - baik BMR maupun BMTverba (djaga-berdjaga) berada di belakang subjek (dia-ija) dan keduanya berpola S-V. Pada contoh (5), terdapat objek (sedekahmoe) yang mengikuti subjek (kamoe) dan verba (boewat), dan objek (sedekahmoe) sehingga berpola S-V-O-K. Adapun pada BMT terdapat pelengkap yang mengikuti subjek (kamoe) dan verba (berboewat) sehingga berpola S-V-Pel. Dengan demikian, afiks ber- yang melekat pada verba BMT cenderung mengubah pola urutan karena afiks ber- cenderung diikuti pelengkap atau keterangan.

\subsubsection{VD + -ken $\rightarrow$ me-+VD+-kan}

Penggunaan VD ditambah akhiran -kan pada BMR dan penggunaan VD yang ditambah konfiks me-kan pada BMT cukup sering terjadi. Pada data perbedaan pembentukan ini ditemukan sebanyak 22 kata $(4,89 \%)$. Beberapa contoh pola ini adalah sebagai berikut.

Tabel 9

\begin{tabular}{|c|c|c|c|c|}
\hline No. & $\begin{array}{l}\text { pasal: } \\
\text { ayat }\end{array}$ & BMR & BMT & $\begin{array}{l}\text { Pola Urutan } \\
\text { (BMR-BMT) }\end{array}$ \\
\hline (1) & $3: 12$ & $\begin{array}{l}\text {...dan Dia nanti bresihken sakali } \\
\text { lesoengnja, }\end{array}$ & $\begin{array}{l}\text {...dan ijapon akan menjoetjikan tempat } \\
\text { pengiriknja, }\end{array}$ & SKVO-SVO \\
\hline$(2)$ & $5: 25$ & serta itoe hakim serahken kamoe... & maka hakim pon menjerahkan dikau... & SVO-SVO \\
\hline (3) & $11: 1$ & dan kabarken dalem negari-negarinja. & $\begin{array}{l}\text { dan mengchabarkan indjil dalam segala } \\
\text { negari mareka-itoe. }\end{array}$ & VK-VOK \\
\hline (4) & $5: 33$ & $\begin{array}{l}\text { tetapi kamoe mesti sampeken soempahmoe } \\
\text { sama Maha Toehan. }\end{array}$ & $\begin{array}{l}\text { melainkan hendaklah kamoe menjampaikan } \\
\text { kapada Toehan akan perkara soempahmoe } \\
\text { itoe. }\end{array}$ & SVOK-SVKO \\
\hline (5) & $23: 13$ & karna kamoe koentjiken karadjaan... & $\begin{array}{l}\text { karena kamoe mengoentjikan karadjaan } \\
\text { sorga... }\end{array}$ & SVO-SVO \\
\hline
\end{tabular}

Berdasarkan contoh di atas, dapat dilihat bahwa kelima verba pada kalimat di atas berfungsi sebagai predikat. Bila dilihat dari pola urutan kata, BMR pada contoh (1), subjek (dia) diikuti keterangan (nanti), verba (bresihken), dan objek (sakali lesoengnja) sehingga berpola S-K-V-O. Adapun, pada BMT, subjek (ijapon) diikuti verba (akan menjoetjikan), dan objek (tempat pengiriknja) sehingga berpola berpola S-V-O. Pada contoh (2) dan (5), tidak ada perbedaan pola urutan kata antara BMR dan BMT, yaitu subjek mendahului verba dan keduanya berpola S-V-O. Pada contoh (3), baik pada BMR maupun BMT tidak memiliki subjek. Pada BMR verba (kabarken) langsung diikuti keterangan (dalem negari-negarinja) sehingga berpola urutan V-K, Pada BMT verba (mengchabarkan) diikuti objek (indjil) dan keterangan (dalam segala negari mareka itoe) sehingga berpola $\mathrm{V}-\mathrm{O}-\mathrm{K}$.
Pada contoh (4), terdapat perbedaan posisi objek pada kalimat BMR dan BMT. Pada BMR, fungsi objek (soempahmoe) mendahului keterangan, sedangkan pada BMT fungsi objek mengikuti keterangan (perkara soempahmoe itu). Oleh karena itu, teks BMR berpola urutan kata S-V-O-K, sedangkan teks BMT berpola S-V-K-O. Dengan demikian, perbedaan morfologis verba berakhiran -ken pada BMR dan me- ditambah VD dan -kan pada BMT tidak mengubah pola urutan $\mathrm{S}-\mathrm{V}(\mathrm{O})$ pada kalimat; kalaupun ada, hanya disisipi keterangan yang posisinya dapat berpindah.

\subsubsection{VD+-ken $\rightarrow$ VD+-kanlah}

Perbedaan pola pembentukan VD ditambah akhiran -ken pada BMT dan VD ditambahh akhiran -kan dan -lah pada BMT dalam data ditemukan sebanyak 11 kata $(2,44 \%)$. Contoh kalimat pola ini adalah sebagai berikut. 
Hotnida Novita Sary: Perbedaan Bentuk Verba pada Bahasa Melayu Tinggi dan ...

Tabel 10

\begin{tabular}{|c|c|c|c|c|}
\hline No. & $\begin{array}{l}\text { pasal: } \\
\text { ayat }\end{array}$ & BMR & BMT & $\begin{array}{l}\text { Pola Urutan } \\
\text { Kata }\end{array}$ \\
\hline 1. & $6: 13$ & ...melainken lepasken saja dari jang djahat. & $\begin{array}{l}\text {...melainkan lepaskanlah kami daripada jang } \\
\text { djahat, }\end{array}$ & VOK-VOK \\
\hline 2. & $10: 8$ & ...boewangken setan-setan... & ...boewangkanlah segala sjaitan... & VO-VO \\
\hline 3. & $10: 14$ & ...serta kebasken haboenja dari kakimoe... & $\begin{array}{l}\text {...dan kebaskanlah haboe jang lekat pada } \\
\text { kakimoe... }\end{array}$ & VOK-VOK \\
\hline 4. & $6: 6$ & ...koentjiken pintoemoe... & ...koentjikanlah pintoenja... & $\mathrm{VO}-\mathrm{VO}$ \\
\hline 5. & $5: 44$ & ...dan mintaken-doa akan orang... & ...dan pintakanlah doa akan segala orang... & VOK-VOK \\
\hline
\end{tabular}

Berdasarkan contoh di atas, dapat dilihat bahawa verba berkedudukan sebagai predikat. Sementara itu, jika dilihat dari segi pola urutan kata, kelima-verba baik pada BMR dan BMT-verba mendahului subjek. Oleh karena itu, tidak terdapat perbedaan antara BMR dan BMT.

\subsubsection{VD+-ken $\rightarrow d i-+\mathrm{VD}+-k a n$}

Berdasarkan data ditemukan 11 kata $(2,44 \%)$ yang memiliki perbedaan pembentukan dengan VD ditambah akhiran -ken pada BMR dan pembentukan dengan afiks $d i$ - ditambah VD serta akhiran -kan pada BMT. Contoh perbedaan pola ini adalah sebagai berikut.

Tabel 11

\begin{tabular}{|l|l|l|l|l|}
\hline No. & $\begin{array}{c}\text { pasal: } \\
\text { ayat }\end{array}$ & \multicolumn{1}{|c|}{ BMR } & \multicolumn{1}{|c|}{ BMT } & $\begin{array}{c}\text { Pola Urutan } \\
\text { Kata }\end{array}$ \\
\hline 1. & $5: 25$ & $\begin{array}{l}\text { sopaja djangan barangkali satroemoe } \\
\text { serahken kamoe... }\end{array}$ & soepaja djangan diserahkannja engkau... & SVO-V(K)S \\
\hline 2. & $111: 2$ & dia lantas soeroehken doewa orang... & maka disoeroehkannja doewa orang... & SVO-V(K)S \\
\hline 3. & $22: 25$ & dia tinggalken bininja... & ditinggalkannja bininja... & SVO-V(K)S \\
\hline 4. & $25: 7$ & dan sediaken pelitanja. & dan disadiakannja soeloehnja. & VO-V(K)S \\
\hline 5. & $12: 20$ & Dia tidak nanti patahken boeloeh... & $\begin{array}{l}\text { Adapon boeloeh rantik jang terkoelai tidak akan } \\
\text { dipatahkannja. }\end{array}$ & SVO-SV(K) \\
\hline
\end{tabular}

Berdasarkan contoh di atas, dapat dilihat bahwa verba pada BMR maupun BMT berkedudukan sebagai predikat. Dalam lima kalimat BMT di atas, keterangan pelaku muncul dalam bentuk klitik -nja. Bila dilihat dari segi pola urutan kata, BMR pada contoh (1) subjek (satroemoe) mendahului verba (serahken) dan objek (kamoe) sehingga berpola S-V$\mathrm{O}$, sedangkan pada BMT subjek (engkau) mengikuti verba (diserahkan) —yang dilekati keterangan pelaku (-nja)—sehingga berpola V(K)-S.

Pada contoh (2), BMR berpola S-V-O, yaitu subjek (dia), verba (soeroehken), objek (doewa orang), sedangkan pada BMT berpola $\mathrm{V}(\mathrm{K})-\mathrm{S}$, yaitu verba (disoeroehkan)—yang dilekati keterangan pelaku (-nja) - dan subjek (doewa orang). Pada contoh (3), teks BMR berpola S-V-O, yaitu subjek (dia), verba (tinggalken), dan objek (bininja), sedangkan teks BMT berpola $\mathrm{V}(\mathrm{K})-\mathrm{S}$, yaitu verba (ditinggalkan)—yang dilekati keterangan pelaku (-nja)—diikuti subjek (bininja).

Pada contoh (4) baik BMR berpola V-O, yaitu verba (sediaken) mendahului objek (pelitanja), sedangkan BMT berpola $\mathrm{V}(\mathrm{K})-\mathrm{S}$, yaitu verba (disadiakan)_yang dilekati keterangan pelaku (-nja)—mendahului subjek (soeloehnja). Pada contoh (5), teks BMR berpola S-K-V-O, yaitu subjek (dia), keterangan (nanti), verba (tidak patahken), objek (boeloeh), sedangkan BMT berpola $\mathrm{S}-\mathrm{V}(\mathrm{K})$, yaitu subjek (boeloeh rantik jang terkoelai) mendahului verba (tidak akan dipatahkan) — ditambah keterangan pelaku (-nja) yang melekat pada verba.

\subsection{8 me-+VD $\rightarrow d i-+\mathrm{VD}$}

Berdasarkan data, ditemukan 32 kata $(7,11 \%)$ yang memiliki perbedaan pembentukan dengan afiks me- ditambah VD pada BMR dan pembentukan 
Hotnida Novita Sary: Perbedaan Bentuk Verba pada Bahasa Melayu Tinggi dan ...

dengan afiks $d i$ - ditambah VD. Contoh kalimat pola ini adalah sebagai berikut.

Tabel 12

\begin{tabular}{|c|c|c|c|c|}
\hline No. & $\begin{array}{c}\text { pasal: } \\
\text { ayat }\end{array}$ & BMR & BMT & $\begin{array}{l}\text { Pola Urutan } \\
\text { Kata }\end{array}$ \\
\hline 1. & $2: 3$ & Maka kapan radja Herodes mendengar itoe & Demi didengar olih radja Herodis akan hal itoe & SVO-VKS \\
\hline 2. & $3: 7$ & $\begin{array}{l}\text { Maka kapan Johannes melihat banjak orang } \\
\text { parisi }\end{array}$ & Apabila dilihat olih Jahja banjak orang parisi & SVO-VKS \\
\hline 3. & $10: 1$ & $\begin{array}{l}\text { Maka sasoedahnja memanggil doewa-blas } \\
\text { moeridnja }\end{array}$ & $\begin{array}{l}\text { HATA maka olih Isa dipanggil kadoewa-belas } \\
\text { moeridnja }\end{array}$ & VO-KVS \\
\hline 4. & $21: 19$ & Lantas Toehan melihat satoe pohon ara... & Maka dilihatnja ada sabatang pokok ara... & SVO-V(K)S \\
\hline 5. & $12: 24$ & Tetapi kapan menengar itoe... & $\begin{array}{l}\text { Tetapi demi didengar orang Parisi akan hal } \\
\text { itoe... }\end{array}$ & VO-VKS \\
\hline
\end{tabular}

Secara keseluruhan, verba pada kelima contoh BMR dan BMT di atas berkedudukan sebagai predikat. Oleh karena verba pada BMT berimbuhan $d i$, kalimat pada BMT merupakan kalimat pasif, berbeda dengan verba pada BMR yang berbentuk aktif. Bila dilihat dari pola urutan, contoh (1) pada teks BMR, subjek (Herodes) mendahului verba (mendengar) dan objek (itoe) sehingga berpola S-VO. Adapun, BMT berpola V-K-S, yaitu verba (didengar), keterangan (olih radja Herodis), dan subjek (akan hal itoe). Hal yang sama juga terjadi pada kalimat (2), BMR berpola urutan S-V-O, yaitu subjek (Johannes), verba (melihat), objek (banjak orang parisi), sedangkan BMT berpola urutan V-K-S, verba (dilihat), keterangan (olih Jahja), subjek (banjak orang parisi).

Pada kalimat (3), pada BMR verba (memanggil) mendahului objek (doewa blas moeridnja) sehingga berpola V-O. Pada BMT terdapat subjek (kadoewa belas moeridnja) yang mengikuti verba (dipanggil) sehingga berpola K-V-S. Kalimat (4), teks BMR berpola S-V-O, yaitu subjek (Toehan), verba (melihat), objek (satoe pohon ara). Adapun pada BMT berpola $\mathrm{V}(\mathrm{K})-\mathrm{S}$, subjek (ada sabatang pohon ara) mengikuti verba (dilihat)-yang dilekati keterangan pelaku (-nja). Kalimat (5), pada BMR tidak terdapat subjek dan verba (menengar) diikuti objek (itoe) sehingga berpola V-O. Adapun, pada BMT verba (didengar) diikuti keterangan (orang Parisi) diikuti subjek (akan hal itoe).

\subsection{9 me-+VD $\rightarrow$ VD}

Perbedaan pembentukan verba dengan afiks meditambah VD pada BMR dan VD pada BMT ditemukan sebanyak 11 kata $(2,44 \%)$. Contohnya sebagai berikut.

Tabel 13

\begin{tabular}{|l|l|l|l|l|}
\hline No. & $\begin{array}{c}\text { pasal: } \\
\text { ayat }\end{array}$ & \multicolumn{1}{|c|}{ BMR } & \multicolumn{1}{c|}{ BMT } & $\begin{array}{c}\text { Pola Urutan } \\
\text { Kata }\end{array}$ \\
\hline 1. & $17: 16$ & Dan saja soedah membawa dia... & Maka hamba bawa akandia... & SVO-SVO \\
\hline 2. & $21: 38$ & bijar kita-orang memboenoeh dia... & marilah kita boenoeh ija... & SVO-SVO \\
\hline 3. & $8: 8$ & Maka itoe kapala menjaoet... & Tetapi sahoet penghoeloe... & SV-VS \\
\hline 4. & $6: 8$ & sabelomnja kamoe meminta. & terdehoeloe daripada kamoe minta $\ldots$ & SV-SV \\
\hline 5. & $22: 29$ & Jesoes menjaoet $\ldots$ & Tetapi sahoet Isa... & SV-VS \\
\hline
\end{tabular}

Berdasarkan lima contoh yang dipaparkan di atas, dapat dilihat bahwa verba berfungsi sebagai predikat dalam kalimat. Kedua bentuk verba pada bagian ini sama berbentuk verba aktif. Bila dilihat dari segi pola urutan kata, kalimat (1) dan (2), baik BMR maupun BMT, tidak terdapat perbedaan pola urutan, keduanya berpola urutan $\mathrm{S}-\mathrm{V}-\mathrm{O}$. Hal yang sama juga terjadi pada kalimat (4), tidak ada perbedaan pola urutan antara BMR dan BMT, keduanya berpola S-V. Kalimat (3), subjek (itoe kapala) pada BMR mendahului verba (menjaoet) dan berpola urutan S-V, sedangkan pada BMT subjek (penghoeloe) berada di belakang verba (sahoet) dan berpola urutan V-S. Hal yang sama juga terjadi pada kalimat 5, pola urutan 
Hotnida Novita Sary: Perbedaan Bentuk Verba pada Bahasa Melayu Tinggi dan ...

kata BMR adalah S-V, sedangkan pada BMT berpola $\mathrm{V}-\mathrm{S}$.

\subsubsection{0 me-+VD+-ken $\rightarrow$ di-+VD+-kan}

Berdasarkan data, ditemukan 11 kata $(2,44 \%)$ yang memiliki perbedaan pembentukan me- ditambah
VD dan akhiran -ken pada BMR serta pembentukan dengan afiks $d i$ - ditambah VD serta akhiran - kan pada BMT. Contoh perbedaan pola ini adalah sebagai berikut.

Tabel 14

\begin{tabular}{|c|c|l|l|l|}
\hline No. & $\begin{array}{c}\text { pasal: } \\
\text { ayat }\end{array}$ & \multicolumn{1}{|c|}{ BMR } & \multicolumn{1}{|c|}{ BMT } & \multicolumn{1}{|c|}{$\begin{array}{c}\text { Pola Urutan } \\
\text { (BMR-BMT) }\end{array}$} \\
\hline$(1)$ & $21: 8$ & ...dan menghamparken dia didjalan. & ...laloe dihamparkannja didjalan. & VOK-V(K)K \\
\hline$(2)$ & $27: 29$ & Dan habis menganjamken satoe makota... & $\begin{array}{l}\text { Dan di-annjamkannja poela saboewah } \\
\text { makota... }\end{array}$ & VO-V(K)S \\
\hline$(3)$ & $22: 22$ & $\ldots$ meninggalken Toehan & ...ditinggalkannja akandia & VO-V(K)S \\
\hline$(4)$ & $9: 35$ & $\begin{array}{l}\text {...dan menjemboehken segala sakit- } \\
\text { penjakit... }\end{array}$ & $\begin{array}{l}\text {..dan disemboehkannja segala sakit- } \\
\text { penjakit... }\end{array}$ & VO-V(K)S \\
\hline$(5)$ & $13: 24$ & $\begin{array}{l}\text { Toehan menghadapken sama dia-orang } \\
\text { lagi satoe peroepamaan jang lain... }\end{array}$ & $\begin{array}{l}\text { soeatoe peroepamaan jang lain poela } \\
\text { dihadapkannja kapada mareka-itoe... }\end{array}$ & SVKO-SV(K)K \\
\hline
\end{tabular}

Berdasarkan contoh di atas, dapat dilihat bahwa kelima verba berkedudukan sebagai predikat. Keterangan pelaku pada BMT melekat pada verba dalam bentuk klitik -nja. Jika dilihat dari segi pola urutan kata, kalimat (1) pada BMR verba (menghamparken) mendahului objek (dia) dan keterangan (didjalan) sehingga berpola urutan V-OK. Pada BMT verba (dihamparkan)_yang dilekati keterangan pelaku (-nja)-mendahului keterangan (didjalan) sehingga berpola $\mathrm{V}(\mathrm{K})-\mathrm{K}$.

Kalimat (2), pada BMR verba (menganjamken) diikuti objek (satoe makota) dan berpola V-O, sedangkan pada BMT verba (di-annjamkan)_yang dilekati keterangan pelaku (-nja)-diikuti subjek (saboewah makota) dan berpola V(K)-S. Hal ini juga terjadi pada contoh (3) dan (4), kalimat pada BMR berpola urutan V-O sedangkan pada BMT berpola urutan V(K)-S. Kalimat 5, pada BMR subjek (Toehan) diikuti verba (menghadapken), keterangan (sama dia-orang lagi), dan objek (satoe peroepamaan jang lain) serta berpola urutan kata S-V-K-O. Pada BMT, subjek (soeatoe peroepamaan jang lain poela) berada di depan verba (dihadapkan)_yang dilekati keterangan pelaku (-nja)_dan keterangan (kapada mareka-itoe) serta berpola urutan $\mathrm{S}-\mathrm{V}(\mathrm{K})-\mathrm{K}$.

\section{SIMPULAN}

Dalam data, dari 450 verba yang berleksem sama, terdapat 139 perbedaan morfologis pada BMR dan BMT. Sementara itu, dari 486 verba yang berleksem berbeda, peneliti menemukan 145 perbedaan morfologis antara BMR dan BMT. Jika dilihat dari bentuk morfologisnya, teks BMR cenderung menggunakan bentuk VD dibandingkan BMT, sedangkan teks BMT cenderung menggunakan bentuk VB.

Kecenderungan penggunaan VB pada BMT disebabkan karena BMT cenderung menggunakan bahasa standar yang menggunakan afiksasi secara konsisten. Hal ini tidak terjadi pada BMR, kalaupun ada hanya dalam jumlah yang tidak terlalu banyak dan tidak konsisten. Berkaitan dengan hal ini pula, BMR cenderung menggunakan bentuk dasar tanpa afiks karena dalam mengungkapkan sesuatu, BMR cenderung menggunakan kata yang lebih singkat, tetapi maknanya dapat tersampaikan dengan baik. Hal ini senada dengan yang diungkapkan Spat (1989) bahwa bahasa lisan-yang dia sebut BMR - bersifat sangat padat, pendek kata, tetapi sudah mampu mengungkapkan arti yang luas. Hal ini berbanding terbalik dengan BMT yang menggunakan kata berafiks yang lebih panjang untuk mengungkapkan sesuatu. Seperti yang diungkapkan Spat (1989), bahasa sastra Melayu-yang dia sebut BMTcenderung panjang dan berbelit.

Dari penghitungan yang dilakukan, sama atau bedanya leksem tidak terlalu memengaruhi frekuensi perbedaan morfologi. Jumlah perbedaan morfologis pada BMR dan BMT-baik yang berleksem sama 
Hotnida Novita Sary: Perbedaan Bentuk Verba pada Bahasa Melayu Tinggi dan ...

maupun tidak - tidak jauh berbeda. Dari sepuluh perbedaan morfologis berleksem sama dan delapan perbedaan morfologis berleksem berbeda, pola yang mendominasi adalah peneliti tampilkan pada tabel di bawah ini.

Tabel 15

\begin{tabular}{|c|c|c|c|}
\hline \multicolumn{2}{|c|}{ Pola perbedaan morfologis } & \multirow{2}{*}{ Verba berleksem sama } & Verba berleksem berbeda \\
\cline { 1 - 2 } BMR & BMT & & 33 \\
\hline VD & VD+-lah & 47 & 35 \\
\hline VD & me-+VD & 33 & 26 \\
\hline VD & ber-+VD & 16 & 19 \\
\hline VD+-ken & me-+VD+-kan & 22 & 14 \\
\hline$m e-+\mathrm{VD}$ & di- $+\mathrm{VD}$ & 32 & \\
\hline
\end{tabular}

Perbedaan antara BMR dan BMT juga ditemukan dalam hal pola urutan kata (S-V-O). Dalam beberapa kasus, ditemukan perbedaan pola urutan kata pada teks BMR S-V(O), sedangkan pada BMT V-S. Perbedaan pola urutan kata ini disebabkan oleh beberapa hal: (1) penggunaan partikel -lah yang mengikuti verba pada BMT; (2) penggunaan partikel -lah menonjolkan verba sebagai fokus pembicaraan sehingga cenderung diletakkan di depan subjek; (3) perbedaan bentuk verba aktif-pasif pada BMR dan BMT yang juga berpengaruh pada pola urutan kata; (4) bentuk aktif lebih menonjolkan subjek daripada perbuatan, sedangkan bentuk pasif lebih menonjolkan perbuatan sehingga berada di depan verba.

Selain itu, bentuk verba transitif-intransitif juga berpengaruh pada pola urutan kata. Perbedaan ini disebabkan oleh bentuk afiksasi yang melekat pada verba, contohnya pada Matius 18:8, pada BMR tertulis: tanganmoe atawa kakimoe (S) djadi (V) sandoengan (Pel.), sedangkan pada BMT: tanganmoe ataw kakimoe (S) mendatangkan (V) sjak (O.). Dengan demikian, melekatnya afiks pada sebuah verba dapat juga mengubah pola urutannya.

Dari penghitungan yang telah dilakukan sebelumnya, kecenderungan bentuk aktif pada BMR sangat tinggi $(89,77 \%)$ sedangkan bentuk pasif rendah (10,23\%). Hal ini berbeda dengan BMT, yang walaupun persentase bentuk aktif lebih banyak $(62,60 \%)$, terdapat kecenderungan bentuk pasif juga cukup besar $(37,40 \%)$. Hal yang sama juga diungkapkan van Wijk (1985:83) bahwa orang Melayu lebih banyak menggunakan bentuk pasif daripada bentuk aktif verba. Hal ini disebabkan orang Melayu cenderung menekankan perbuatan daripada subjek yang bertindak. Perbuatan lebih kuat tampil dalam bentuk pasif dibanding bentuk aktif. Dalam bentuk aktif, subjek yang berada di depan verba atau perbuatan.

\section{DAFTAR PUSTAKA}

Alwi, Hasan, dkk. 2003. Tata Bahasa Baku Bahasa Indonesia, ed. ketiga. Jakarta: Balai Pustaka

Collins, James T. 2005. Bahasa Melayu Bahasa Dunia: Sejarah Singkat. Jakarta: Yayasan Obor Indonesia

Chambert-Loir, Henri. 2009. Sadur: Sejarah Terjemahan di Indonesia dan Malaysia. Jakarta: Kepustakaan Populer Gramedia.

de Hollander, J. J. 1984. Pedoman Bahasa dan Sastra Melayu. Jakarta: Balai Pustaka

Hamidy, U.U. 1983. Riau sebagai Pusat Bahasa dan Kebudayaan Melayu. Pekanbaru: Bumi Pustaka Jasin, H.B. 1956. Kesusastraan Dunia dalam Terjemahan Indonesia. Jakarta: Balai Pustaka

Kridalaksana, Harimurti. 1991. Masa Lampau Bahasa Indonesia: Sebuah Bunga Rampai. Jakarta: Kanisius 
Hotnida Novita Sary: Perbedaan Bentuk Verba pada Bahasa Melayu Tinggi dan ...

1999. Sintaksis: Tata Bahasa Deskriptif Bahasa Indonesia. Jakarta: Fakultas Sastra

Universitas Indonesia

dkk. 2007. "Dasar-dasar Leksikologi dan Leksikografi: Bahan Pelatihan dan

Penyusunan Kamus Dwi Bahasa (Indonesia/Melayu-asing, Indonesia/Melayu-daerah)”. Diktat. Depok:

Pusan Leksikologi dan Leksikografi, Fakultas Ilmu Pengetahuan Budaya Universitas Indonesia

2007. Pembentukan Kata dalam Bahasa Indonesia. Jakarta: Gramedia Pustaka Utama

Latuihamallo, P.D. 1994. "Penerjemahan Alkitab di Indonesia; Tinjauan Historis," dalam Persebaran Firman Di Sepanjang Zaman, halaman 39-52. Lembaga Alkitab Indonesia dan PT BPK Gunung Mulia, diunduh dari sabda.org (24 April 2009)

McGavran, Grace W. 1989, 1991, 1993, 1996. “Alkitab yang Bungkam dalam Bahasa Nusantara (Indonesia, abad ke-17 dan ke-18)," dalam Alkitab di Seluruh Dunia: 48 Kisah Nyata, halaman 11-16. Bandung: Lembaga Literatur Baptis, diunduh dari sabda.org (24 April 2009)

Munday, Jeremy. 2001. Introducing Translation Studies: Theory and Applications. New York: Routledge

Nida, E dan Charles Taber. 1969. The Theory and Practice of Translation. Leiden: United Bible Societies

Poerwadarminta, W.J.S. 1966. Kamus Umum Bahasa Indonesia, cetakan keempat. Jakarta: Balai Pustaka

Respati, Yosepha. 2007. "Terjemahan Beranotasi: Novel Under the Dragon: Travels in a Betrayed". Tesis pada FIB UI, Depok

Sastrasoeganda, Koewatin. 1986. Kitab jang Menjatakan Djalannya Bahasa Melajoe. Jakarta: Balai Pustaka

Slametmuljana. 1969. Kaidah Bahasa Indonesia. Jakarta: Nusa Indah Ende Flores

Soesilo, Daud H. 2001. Mengenal Alkitab Anda. Jakarta: Lembaga Alkitab Indonesia.

Spaat, C. 1989. Bahasa Melayu: Tata Bahasa Selayang Pandang. Jakarta: Balai Pustaka

Sumardjo, Jacob. 2004. Kesusastraan Melayu Rendah: Masa Awal. Yogyakarta: Galang Press

Swellengrebel, J.L. 2006. Mengikuti Jejak Leijdecker. Jakarta: Lembaga Alkitab Indonesia

Teeuw, A. 1961. A Critical Survey Of Studies on Malay and Bahasa Indonesia. 'S-Gravenhage: Martinus Nijhoff

Utorodewo, Felicia N., dkk. 2004. Bahasa Indonesia: Sebuah Pengantar Penulisan Ilmiah. Depok: Universitas Indonesia Press

Van Ophuijsen, C.H. A. 1983. Tata Bahasa Melayu. Jakarta: Penerbit Djambatan

van Wijk, D. Gerth. 1985. Tata Bahasa Melayu. Jakarta: Penerbit Djambatan

Winckel, Eduard F.. 1944. Handbook of the Malay Language. California: P.D and Ione Perkins

Winstedt, R.O. 1952. Malay Grammar. London: Clarendon Press

Wojowasito, S. 1970. Pengantar Sintaksis Indonesia. Malang: FKSS IKIP Malang

Yin, Robert K. 2005. Studi Kasus: Desain dan Metode. Jakarta: PT Raja Grafindo Persada

Yusuf, Muri. 2007. Metodologi Penelitian. Padang: UNP Press. 